\title{
OUTPUT RESPONSE OF STAPLE FOOD CROPS IN NIGERIAN AGRICULTURE $(1990$ - 2005)
}

\author{
AGWU, N. M.; C.S. ALAMBA AND J.U. NWACHUKWU \\ College of Agribusiness and Financial Management, \\ Michael Okpara University of Agriculture, Umudike \\ P.M.B 7267, Umuahia, Abia State \\ E-mail: namak71@yahoo.com.
}

\begin{abstract}
This study examined the output response of staple food crops in Nigerian Agriculture from 1990 - 2005. Secondary data from the Central Bank of Nigeria statistical bulletin and those from the food and agriculture database as well as from the National Bureau of statistics were used for the analysis. The analysis include the exponential or log linear trend multiple regression. Output and time were all positive and significant atone percent. In the regression results, labour, fertilizer and land area cultivated were significant at various levels. However, land had a negative coefficient. The study recommended that the subsidy on fertilizer should be sustained in other to obtain the needed output from these staple crops. Educating farmers on the right use of fertilizer and extension agents trained and deployed to the rural areas will also be steps in the right direction.
\end{abstract}

Keywords: Output Response, Staple Food Crops, Output and Trend.

\section{INTRODUCTION}

The agricultural sector is an important sector and an important part of any nation's economy. It represents a significant part of national GDP and directly contributes to the incomes of a substantial proportion of the population - especially in the case of the poorer people (Philip, Henry and Tevita, 2008). Since the agricultural sector of great importance to Nigeria, knowledge of its output responsiveness may help policy makers use the sector to spearhead external and internal adjustment processes. Infact, any hope of reviving the economy will necessarily have to include strategies focused on the agricultural sector. If agriculture is highly responsive, then policy reform induced changes in relative prices could bring about increased exports to resolve external balance. Also, agricultural response in the form of increased food production could help moderate inflation and this will contribute to the process of internal adjustment (Muchapondwa, 2009).

Supply (output) response in agriculture has a crucial research issue related with agricultural terms of trade policies, price, etc in a developing country like Nigeria. Selfsufficiency in the production of agricultural commodities such as rice production is now an important political economic goal of the Nigerian government (Bello, 2004).

This research work focused on staple food crops. They are agricultural food crops which are eaten regularly and in such quantities as to constitute the dominant part of the diet and supply a major proportion of energy and nutrient needs. The most important of these staple crops cultivated in Nigeria include rice, corn, wheat and potatoes. Others are barley, millet, oats, rye, sorghum, soybeans, sweet potatoes and yams. In a broad sense, this paper has its objective as examining the output response of these staple crops in Nigeria between 1990 and 2005. Specifically, it estimated the trend behaviour of these various staple food crops in Nigeria, ascertained the determinants of output of these staple food crops and made some policy recommendations based on the findings. 


\section{RESEARCH METHODOLOGY}

\section{Study Area}

The study area is Nigeria. Nigeria is located between Latitude $4^{0} 20^{\prime}$ and $14^{0}$ North and between Longitudes $3^{0} 20^{\prime}$ and $14^{0} 30^{\prime}$ 'East, covering a geographical space of 923, 768 square kilometers. It is multi-ethnic society with population of $140,003,542$ persons and a population density of 152 per square kilometer (NBS, 2006; CBN, 2006).

Despite its rich oil wealth, Agriculture is the largest single sector of the economy providing employment for a significant segment of the work force and constituting the mainstay of Nigeria's large rural community which accounts for nearly two-thirds of the population. The proportion of the GDP attributable to agriculture hovers between $30-40$ percent (CBN, 2006). The favourable climatic conditions and vegetation makes Nigeria able to provide crops and livestock. Some of the staple crops grown in Nigeria include rice, maize, wheat, sorghum, millet, oats, rye, potatoes, yam, cassava etc (CBN, 2002).

\section{Data Sources}

The data used for the study were from secondary sources collected from available information over a period of 1990 - 2005 from the Central Bank of Nigeria (CBN) annual reports and statements of accounts, National Bureau of Statistics (NBS) and other financial and economic reviews, and Food and Agriculture Organization (FAO) statistical data base.

\section{Analytical Procedure}

To realize the objectives set out for this study, the exponential or log linear trend or what is variously called the "left side semi-log" analysis was used to realize the first objective, which involved the modeling of the trends of supply (output) of the staple food crops in Nigeria between 1990 - 2005. This followed Diebold (2007), Udom (2006) and Okoye et al (2008). The second objective was achieved using multiple regression. The models are specified as follows:

Ln $\quad \mathrm{Y}=\mathrm{b}_{\mathrm{o}}+\mathrm{b}_{1} \mathrm{t}$

$\mathrm{Y}=$ Output of staple crops

$\mathrm{T}=$ Time trend available

$b_{0}, b_{1}=$ regression parameters or coefficients to be estimated.

In the case of multiple regression, the model is specified thus;

$$
\mathrm{Y}=\mathrm{f}\left(\mathrm{X}_{1}+\mathrm{X}_{2}+\mathrm{X}_{3}+\mathrm{X}_{4}+\mathrm{X}_{5}+\mathrm{e}\right)
$$

Where: $\mathrm{Y}=$ Output of staple food crops ('000 tons)

$\mathrm{X}_{1}=$ Consumer price index $=2003=100$

$\mathrm{X}_{2}=$ Average total rainfall $(\mathrm{mm})$

$\mathrm{X}_{3}=$ Fertilizer consumption (tons)

$\mathrm{X}_{4}=$ Agricultural labour (Number of persons)

$\mathrm{X}_{5}=$ Land area cultivated with staple crops $(\mathrm{Ha})$

$\mathrm{e}=$ error term

The model was subjected to four functional forms, viz:

Linear form:

$\mathrm{Y}=\mathrm{b}_{\mathrm{o}}+\mathrm{b}_{1} \mathrm{x}_{1}+\mathrm{b}_{2} \mathrm{X}_{2}+\mathrm{b}_{3} \mathrm{x}_{3}+\mathrm{b}_{4} \mathrm{x}_{4}+\mathrm{b}_{5} \mathrm{x}_{5}+\mathrm{e}$

Semi log form:

$\mathrm{Y}=\mathrm{b}_{\mathrm{o}} \log \mathrm{x}_{1}+\mathrm{b}_{2} \log \mathrm{x}_{2}+\mathrm{b}_{2} \log \mathrm{x}_{2}+\mathrm{b}_{3} \log \mathrm{x}_{3}+\mathrm{b}_{4} \log \mathrm{x}_{4}+\mathrm{b}_{5} \log \mathrm{x}_{5}+\mathrm{e}$

Exponential form:

$\log Y=b_{o}+b_{1} x_{1}+b_{2} x_{2}+b_{3} x_{3}+b_{4} x_{4}+b_{5} x_{5}+e$

Double log form:

$\log Y=b_{o} \log x_{1}+b_{2} \log x_{2}+b_{2} \log x_{2}+b_{3} \log x_{3}+b_{4} \log x_{4}+b_{5} \log x_{5}+e$

The one that gave the best fit was chosen as the lead equation. 
RESULTS AND DISCUSSION

Output and Time Trend for the Staple Food Crops in Nigeria between 1990 and 2005

Table 1: Estimated Output Trends for Staple Food Crops in Nigeria.

\begin{tabular}{lllll}
\hline & Coefficients & $\mathbf{R}_{2}$ & F - value & DW \\
\hline Constant & 64861.408 & & & \\
Time & $(20.764)^{* * *}$ & & & \\
& 2739.560 & & & \\
& $(8.480)^{* * *}$ & .837 & 71.917 & 1.912 \\
\hline
\end{tabular}

Source: Computations from Data, 2010.

Note: Figures in parenthesis are t-values; $* * *$ denote $1 \%$ level of significance

The output trend equation as obtained from analysis is presented in Table 1 above. The equation had a good fit. This is attested to by the high $\mathrm{R}^{2}$ value of 0.837 which is 83.7 percent and high F-value of 71.917 Output and time were all significant and positive at one percent level. This implies that there has been a positive and increasing output of staple food crops in Nigeria within the study period. This goes to show that government policies towards staple food crops production have been favourable. This result is consistent with that of Okoye et al (2008).

Determinants of Staple Food Crops Output in Nigeria (1990 - 2005)

Table 2: Ordinary Least Square of the Determinants of Staple Food Crops Output in Nigeria

\begin{tabular}{|c|c|c|c|c|}
\hline Variables & Linear & Semi-log & Double log & Exponential \\
\hline Constant & $\begin{array}{l}74799.703 \\
(1.916)^{* *}\end{array}$ & $\begin{array}{l}-96012.294 \\
(0.127)\end{array}$ & $\begin{array}{l}9.518 \\
(2.320)^{* *}\end{array}$ & $\begin{array}{l}11.242 \\
(15.532) * * *\end{array}$ \\
\hline CPI & -108.475 & -4968.251 & -0.047 & -0.001 \\
\hline$(2003=100)$ & $(-1.220)$ & $(-0.420)$ & $(-0.380)$ & $(0-517)$ \\
\hline Average & -0.266 & -5858.801 & -0.020 & $-2.91 \mathrm{E}-006$ \\
\hline Rainfall (mm) & $(-0.658)$ & $(-2.791) * * *$ & $(-0.905)$ & $(-0.688)$ \\
\hline Fertilizer (tons) & $\begin{array}{l}-0.413 \\
(-3.789) * * *\end{array}$ & $\begin{array}{l}3102.523 \\
(0.158)\end{array}$ & $\begin{array}{l}0.625 \\
(3.034) * * *\end{array}$ & $\begin{array}{l}-1.74 \mathrm{E}-007 \\
(-0.153)\end{array}$ \\
\hline Agric. labour (No of persons) & $\begin{array}{l}3.077 \\
(1.272)\end{array}$ & $\begin{array}{l}42763.779 \\
(2.429) * * *\end{array}$ & $\begin{array}{l}0.453 \\
(2.323) * *\end{array}$ & $\begin{array}{l}3.26 \mathrm{E}-005 \\
(1.286)\end{array}$ \\
\hline Land area $(\mathrm{Ha})$ & $\begin{array}{l}-3.855 \\
(-4.664) * * *\end{array}$ & $\begin{array}{l}-23741.615 \\
(-0.548)\end{array}$ & $\begin{array}{l}-0.342 \\
(-2.06)^{*}\end{array}$ & $\begin{array}{l}-8.73 E-006 \\
(-0.456)\end{array}$ \\
\hline $\mathrm{R}^{2}$ & 0.678 & 0.696 & 0.708 & 0.692 \\
\hline $\mathrm{F}$ - ratio & 4.629 & 0.915 & 4.510 & 0.899 \\
\hline DW & 2.482 & 2.510 & 2.480 & 2.56 \\
\hline
\end{tabular}

Source: Computations from Data, 2010. Note: Figures in parenthesis are $\mathrm{t}$ - values; $*, * *, * * *$, denote $10 \%, 5 \%$ and $1 \%$ levels of significance respectively.

The double logarithm functional form was chosen as the lead equation based on statistical and econometric considerations such as the $\mathrm{R}^{2}$ value, $\mathrm{F}$ - ratio - value, number and degree of significant variables and absence of auto - correlation error in the model as measured by the Durbin Watson (DW) estimate gauge.

Time series data such as these used in the study usually show signs of auto correlation and non-stationarity when applied with OLS. However, such could be eliminated by some transformation, example logging and/or by differencing. After which the Durbin Watson (DW) gauge is used to check the presence or absence of auto correlation and non-stationarity. The DW estimates ranges from 1.5 to 2.5 and any value outside the boundary is not acceptable as there is the presence of auto correlation and non-stationarity. The $\mathrm{R}^{2}$ value of 
this functional form was 0.708 . This goes to show that 70.8 percent of variability in the model was explained. This also gives a good fit for the model. The results also show the Fratio to be 4.510 and the DW estimate of 2.480.

From the result of the analysis, fertilizer used in the cultivation of the crops, agricultural labour force and total land area cultivated with staple food crops were significant at various levels. Fertilizer was with a positive coefficient and significant at one percent level. This implies that as the use of fertilizer for staple food crops increases, output in expected to increase. In other words, any one percent increase in fertilizer use, output of staples in Nigeria increases by 6.25 percent. This result is in line with that of Mushtaq and Dawson (2003). Area of land cultivated was also significant at 10 percent level; but with a negative coefficient. This implies that the expansion in the land cultivated did not contribute to output. This result is in contrast to a prior expectation and those of previous studies like Arbar et al (2002), Hallam (2004) and Rahji and Adequni (2008). Given the fact that there has been improvement in technology or improvement in resource use including land, the result is plausible. Agricultural labour was positive and significant at 5 percent level. This implies that there is a positive relationship between labour which is a resource and output of staple food crops within the study period.

\section{CONCLUSION}

This work concentrated on agricultural output response taking into account staple food crop production using the objectives raised. The Ordinary Least Square method was used in estimating the determinants of output for staple food crops. Fertilizer had a positive coefficient and also significant. So also area of land cultivated as well as agricultural labour. The study therefore recommended that: more enlightenment on the use and benefits of fertilizer be given to farmers especially small holder farmers who produce the bulk of these staples. Government should continue to subsidize fertilizer prices. Also labour as an input deserves attention and modernization. To this end, mechanization of farm activities should be encouraged alongside with its subsidies. Tractor hiring units should be established and repositioned in states where they are non-existent. Furthermore, the study recommended that extension agents should be deployed to more areas, infact, there is every need that more agents should be trained and equipped to go into rural areas where small holder farmers who produce the bulk of these staples reside.

\section{REFERENCES}

Abrar, S.Q., Morrissey and T. Rayer (2002): Supply Response of Peasant Farmers in Ethiopia: A Farm Level Profit Function Analysis. Credit Review Paper No. 02/16 Pp. $1-49$.

African Development Bank (ADB) (2006): National Programme for Food Security (NPFS) Staff Appraisal Report.

Central Bank of Nigeria (CBN). Annual Reports and Statement of Accounts. Various Issues.

Diebold, F.X. (2007). Elements of Forecasting $4^{\text {th }}$ ed South Western College Publishing, Cincinnati, Ohio.

Muchapondwa, E. (1999). Supply Response of Zimbabwean Agriculture: 1970 - 1999 School of Economics, University of Capecown.

Food and Agriculture Organization (FAO): FAO Statistical Data base.

Hallam, D. (2004): Analysis of Agricultural Supply Response in Economics in transition. Options Medierteraneennes - series B-ne 22. Agricultural Price Reform under Transition in Bulgaria, Romania and Slovenia $124-131$. 
Mushtaq, K. and Dawson, P.J. (2003). Yield Response in Pakistan Agriculture: A Cointegration Approach. Proceedings of the $25^{\text {th }}$ International Conference of Agricultural Economics (IAAE) held at Durban South Africa 16 - 22 August, 2003.

National Bureau of Statistics (NBS): Statistical Bulletin of the Federal Office of Statistics Various Issues.

National Population Commission [NPC] (2007). Details of the Breakdown of the 2006 National Population Census Schedule 11B - 179.

Ojiako, I.A., G.N. Asumugha, C.I. Ezedinma and N.E. Uzokwe (2007). Analysis of Production Trends in the Major Root and Tuber Crops in Nigeria, $1961-2005$ Research on Crops 8(2): 371 - 380.

Okoye, B.C., G.N. Asumugha, C.A. Okezie, L. Tanko and C.E. Onyenweaku (2008). Econometric Assessment of the Trend of Cocoyam Production in Nigeria, 19960/61 2003/06. Agricultural Journal (Medwell online) 3(2): 99 - 101. 